\title{
«A Cliometric Counterfactual: What if There Had Been Neither Fogel nor North? »
}

\author{
$\underline{\text { Auteurs }}$ \\ Claude Diebolt, Michael Haupert \\ Document de Travail n $2017-04$
}

Février 2017

\begin{abstract}
Faculté des sciences économiques et de gestion
\end{abstract}

61 avenue de la Forêt Noire F-67085 Strasbourg Cedex

Secrétariat du BETA

Géraldine Del Fabbro Tél. : (33) 0368852069 Fax : (33) 0368852070 g.delfabbro@unistra.fr www.beta-umr7522.fr 


\title{
A Cliometric Counterfactual: What if There Had Been Neither Fogel nor North?
}

\author{
By Claude Diebolt* and Michael Haupert ${ }^{\dagger}$ \\ BETA-CNRS, University of Strasbourg: cdiebolt@ unistra.fr \\ University of Wisconsin-La Crosse: mhaupert@uwlax.edu
}
Presented at the American Economic Association Annual Meeting Chicago, January 7, $2017^{1}$

\begin{abstract}
1993 Nobel laureates Robert Fogel and Douglass North were pioneers in the "new" economic history, or cliometrics. Their impact on the economic history discipline is great, though not without its critics. In this essay, we use both the "old" narrative form of economic history, and the "new" cliometric form, to analyze the impact each had on the evolution of economic history.
\end{abstract}

Keywords: Cliometrics, Economic History, Methodology, Economics, History JEL codes: A12, B41, C18, C80, N01 


\section{Introduction}

In December of 1960 the "Purdue Conference on the Application of Economic Theory and Quantitative Techniques to Problems of History" was held on the campus of Purdue University. ${ }^{2}$ It is recognized as the first meeting of what is now known as the Cliometric Society. ${ }^{3}$ While it was the first formal meeting of a group of like-minded applicants of economic theory and quantitative methods to the study of economic history, it was not the first time such a concept had been practiced or mentioned in the literature. ${ }^{4}$ Cliometrics was a long time in coming, but when it arrived, it eventually overran the approach to the discipline of economic history, leading to a bifurcation of the economists and historians who practice the art, and the blurring of the distinction between cliometricians and theorists who use historical data.

Clio's roots are historical in nature, and its focus on theory has actually come full circle over the last century and a half. A mathematical movement in the economics discipline, advanced computing technology, and a shift in the focus of the role of history within economics all contributed to the proliferation of the "new" economic history that rewrote the landscape of the discipline. The emphasis on theory and formal modeling that distinguishes cliometrics from the "old" economic history now blurs the distinction between economic history and economic theory, to the extent that the need for economic historians is questioned, and indeed no longer considered necessary in many economics departments. ${ }^{5}$

Because of their pioneering work in the "new" economic history movement of the 1960s, Robert Fogel and Douglass North, who shared the Nobel Prize in Economic Science in 1993, had a substantial impact on economic history. Both were leading figures within the field of "new" economic history, i.e. cliometrics, and the committee recognized them for having renewed research in economic history by applying economic theory and quantitative methods in order to explain economic and institutional change. But economic historians credit them with more than their impact on the cliometric movement. They impacted the discipline in ways that helped to deepen, broaden, and advance the practice, teaching, and understanding of what economic history is, how it contributes to our understanding of the world, and why it matters.

Further, the announcement reads: "Modern economic historians have contributed to the development of economic sciences in at least two ways: by combining theory with quantitative methods, and by constructing and reconstructing databases or creating new ones. This has made 
it possible to question and to reassess earlier results, which has not only increased our knowledge of the past, but has also contributed to the elimination of irrelevant theories. It has shown that traditional theories must be supplemented or modified to enable us to understand economic growth and change."6

The Nobel Prize announcement specifically cited the contributions of each. Fogel's "foremost work concerns the role of the railways in the economic development of the United States, the importance of slavery as an institution and its economic role in the USA, and studies in historical demography." Of North, they said that he "has studied the long-term development of Europe and the United States, and . . analyzed the role institutions play in economic growth."

While there are many ways they impacted the discipline, we are going to focus in this work on two primary impacts. We will look at the impact that North had on the discipline during the six years he and William Parker edited the Journal of Economic History. For Fogel, we will focus on his seminal research on the railroads and the reverberations it had throughout economic history, and economics in general.

In true clio fashion we use both narrative and theoretical approaches to answer our question. We consider the question of clio's relevance by answering a question Fogel himself posed: will it be relevant in fifty years? To answer this question we consider the impact of his railroad research, published just over fifty years ago. In regard to North, we examine a change in emphasis: the acceleration of the movement of published research in the JEH from narrative to cliometric form during the North-Parker editorial years and how the change in emphasis changed the course of the journal's publication direction permanently toward clio type research. We identify this time period as critical to the growth of clio, using an outlier model.

\section{Brief history of Clio $^{7}$}

Cliometrics has been defined and summarized in numerous scholarly articles. ${ }^{8}$ It is the application of economic theory and quantitative techniques to the study of history. The name, the joining of Clio (the muse of history), with metrics ("to measure," or "the art of measurement"), was allegedly coined by economist Stanley Reiter while collaborating with economic historians Lance Davis and Jonathan Hughes. ${ }^{9}$ 
Cliometrics today is closely related to, but not necessarily the same thing as its progenitor, economic history. While there is considerable overlap between the membership of the Cliometric Society and its American brethren, the Economic History Association, the latter has many more members who reside in history departments than does the Cliometric Society. Indeed, one of the great criticisms of the cliometric movement is the wedge that it has driven between the practitioners of economic history in history and economics departments ${ }^{10}$ due to its focus on quantitative measures and neoclassical theory. ${ }^{11}$

The clash between cliometricians and historians today is not all that different from the clash between economists and historians that has been going on now for more than a century. Carl Menger (1884) compared historians to foreign conquerors, complaining that they were forcing their terminology and methods on economists. Half a century later, T. S. Ashton (1946) accused those who objected to the idea that economic theory should be applied to history of not truly understanding the nature of economics. 
In fact, the discipline of economic history originated largely as a revolt against classical theory and in its early years it shunned the use of statistical techniques. By the 1920s the attitude toward theory and statistics began to soften. Cliometrics is the continuation of this theoreticalquantitative tradition now nearly a century old, and fortified by advances in economic theory, the melding of economics with approaches from other disciplines, and the growth of computing power. The latter has had profound impacts on the ability to analyze and disseminate data.

Arguing against those who cliometricians would later label "old" economic historians, Simon Kuznets claimed that little would be gained from a study of the past unless it was systematic and quantitative. He argued that was the only way to weigh the relative effects of factors and events. As a student of Kuznets, it is no surprise that Fogel harbored the same sentiment.

The "new" economic history can be dated to the 1957 joint meeting of the EHA (founded in 1940 by "old" economic historians Anne Bezanson, Arthur Cole, Edwin Gay, Harold Innis and Earl Hamilton) and the Conference on Research in Income and Wealth (under the guidance of the NBER). In particular, two joint papers by Alfred Conrad and John Meyer (1957 and 1958) constituted the manifesto for the new era. The first paper, on methodology, explained what scientific method was really all about and how it applied to economic historians. Parker (1980) cites the second paper as one of the most influential in the evolution of economic history. It added enormous force to the methodological prescription by claiming to follow it in an analysis of the profitability of slavery on the eve of the Civil war. The meeting produced a volume edited by Parker (1960), which included such path breaking work as Robert Gallman's estimates of commodity output, the farm gross product and investment series produced by Marvin Towne and Wayne Rasmussen, Douglass North's balance of payments estimates, and Stanley Lebergott's wage series.

Kuznets may have inspired the cliometric movement, but it was Robert Fogel who reunified economics and history. He used the latest techniques of modern economics and gathered reams of historical data to reinterpret American economic growth in sectors as diverse as railroads, slavery, and nutrition. Rather than conjecture about the causes of growth, he carefully measured them. He pioneered the use of large-scale cross-sectional and longitudinal 
data sets harvested from original sources to examine policy issues. McCloskey (1992) credited his contributions with opening new ways to the past.

Fogel's breakthrough work was Railroads and American Economic Growth. At the time of its publication, economists believed they had established that modern economic growth was due to certain important industries having played a vital role in development. Fogel set out to measure this impact, which he did with extraordinary precision. He constructed a counterfactual to highlight the contributions of the railways to the growth of the American economy. The result was not what economists or historians expected. He famously found that the railroad was not absolutely necessary in explaining economic development and that its effect on the growth of GNP was minimal. Few books on the subject of economic history have made such an impression as Fogel's. His use of counterfactual arguments and cost-benefit analysis made him an innovator of economic historical methodology, but not universally loved. Fritz Redlich (1965), for example, accused him of "fictitious quasi-history" for his emphasis on the counterfactual. $\mathrm{He}$ acknowledged the value of counterfactual analysis, but thought it was social science research, not historical. ${ }^{12}$

This approach formed his major works on slavery and demography as well. ${ }^{13}$ Fogel recognized early in his career that to answer such questions much greater use had to be made of quantitative evidence, so he mastered the most advanced analytical and statistical methods available and successfully employed them in his research. Herein was the difference between the "old" economic history and the "new:" The use of newly created data series and cutting edge techniques - made more useful, applicable, powerful and easy to replicate and reconsider, with the growth of computing power, to bring a finely focused eye on a problem.

Fogel was not the first to use a form of identifying opportunity costs known as counterfactual analysis, but he was the most extensive user of it and became famous (infamous?) for his use of the technique in his landmark railroad study. Counterfactual analysis is the idea of determining the impact of an event or factor by considering what would have happened in its absence. Before Fogel, the concept was proposed by Fritz Machlup (1952) and Conrad and Meyer (1957 and 1958). 
Like Fogel, Douglass North made his initial impact with research on the American economy. However, whereas Fogel disputed the importance of one sector of the economy in explaining economic growth, North focused on the impact that individual sectors could have in explaining economic outcomes. He sought to explain the causes of growth in the antebellum American economy. Starting with an export based model he had previously formulated, he showed how one sector (the cotton industry) could stimulate development in other branches, ultimately leading to specialization and interregional trade.

North also focused on quantification early on, measuring the impact of decreased transoceanic shipping costs. His surprising finding was not that shipping costs decreased, which was widely recognized at the time, but that it was not technology, so much as institutional changes, such as a decrease in piracy and faster turnaround times in port, that were the source of the decreased costs. This focus on institutions would become North's mantra for the remainder of his career.

Claudia Goldin (1995) notes that the cliometric revolution pitted young turks, or "theorists" as they were called by the old timers, against those "old" economic historians who were more likely to be historians and less likely to rely on quantitative methods. They accused the newcomers of bringing economic theory to history without a proper understanding of the facts (a familiar battle cry). Thomas Cochran (1969) characterized the disagreement as one about the choice of models. The old guard claimed that realistic models had to be too highly generalized or too complex to allow the assumption of mathematical relationships. The "new" economic historians, however, were primarily interested in applying operative models to economic data. There was a difference in method between new and old economic historians that could not be ignored. The models preferred by the new economic historians were quantitative and mathematical, while those used by "sociological economic historians" tended to be narrative.

Cliometrics got the platform it needed to take off when North and Parker were named editors of the Journal of Economic History beginning with the 1961 volume. Robert Whaples (1991) found that the journal led the EHA meetings (a selection of whose papers were represented in the Tasks issue) in the new cliometric methods. From 1956-60, 10\% of the papers were "clio," but only 6\% of the Tasks articles featured cliometrics. From 1961-65 the numbers 
were $16 \%$ and $15 \%$; from $1966-70,43 \%$ and $18 \%$ respectively, and from 1971-75 they skyrocketed to $72 \%$ in the journal and $40 \%$ at the conference.

It is no surprise the JEH led the conference presentations in moving toward the clio approach. During the transition phase (1961-66, the years of the North-Parker editorship) the journal was decidedly "clio friendly" while the conference, whose program was guided by the president overseeing it, was still in the hands of the "old guard." EHA presidents during these years were "old guard” members EAJ Johnson (1961-2), George Rogers Taylor (1963-4), and Harold Williamson (1965-66). In 1967-68 Alexander Gerschenkron, who was trained in the old school, but mentored many of the leading practitioners of the "new" economic history in his Harvard workshop, was named president.

\section{Robert Fogel}

In 1993 Robert Fogel shared the Nobel Prize in Economics with Douglass North for having renewed research in economic history. He was born in New York City in 1926 to Russian immigrant parents. Their reverence for learning encouraged his academic pursuits. He earned degrees at Cornell (BA 1948), Columbia (MA 1960), and Johns Hopkins (PhD 1963). His interest in economic history was precipitated during his undergraduate days at Cornell by the widespread pessimism about the future of the economy during the second half of the 1940s. As he pursued his post-graduate studies he became aware of how little was actually known about the large processes of economic growth, and he began to focus on more discrete issues, such as the nature and magnitude of the contribution of particular technologies to growth. In order to answer such questions he set out to master the most advanced analytical and statistical methods that were then taught in the economics department. It was only later that he would discover that the training program he had worked out for himself was unorthodox for an economic historian.

While at Columbia he studied with George Stigler (who he would later join on the faculty at Chicago, and succeed as the Walgreen Chair in 1981) and Carter Goodrich, who encouraged him to pursue his doctoral work with Simon Kuznets at Johns Hopkins. Fogel presented a thesis proposal to Kuznets in early 1959 entitled "Notes on the Influence of the Railroads on American Economic Growth, 1830-1890." Within it he outlined seventeen proposed subjects regarding the railroad, including economies of scale and the population growth attributable to railroads, capital formation in railroads, and comparisons of social savings in other countries. His resulting book, 
which followed his JEH paper, covered only two of the seventeen proposed subjects. He was, even as a graduate student, building a project that would endure for half a century. His selfestablished fifty-year rule required thinking on a grand scale. It's important if it will matter in fifty years. And if it is to matter fifty years from now, it will have to be grand. ${ }^{14}$

As a testament to the staying power of Railroads, we looked at the citation rate over the fifty year period since its publication and compared it with other works in economic history (Fig 1a). The comparison set is composed of the 50 most cited books reviewed in the JEH between 1941, when the journal debuted, and 1966 (i.e. fifty years ago). The choice of comparing Railroads to only the top 50 books diminishes the impact that Railroads has had over time, because it obviously increases the citation rate of the comparison group. And yet, even against such august competition, we see that Fogel fares very well. Railroads was not a passing phenomenon. Its relevancy has remained strong, and in fact, as measured by citations, has gotten stronger over the past decade. The general trend of top cited books over time is a more gradual increase in citations over the first two decades after their publication, followed by a leveling off. Fogel's citation record is more varied, but shows strong growth over the last decade.

Fogel left Johns Hopkins with a research strategy that would keep him going for decades. He was determined to measure the impact of key scientific and technological innovations on the course of economic growth. His groundbreaking work was due in part to the plunging cost of data processing, made possible by rapid advances in computer software, which made it feasible to work with ever-larger data sets. Fogel believed that "the major obstacle to the resolution of most of the issues in history and economics . . is the absence of data rather than the absence of analytical ingenuity or credible theories." (Engerman et al 29)

Before Fogel showed what a small impact railroads had on the economy, using new economic history techniques, in a classic example of its power to overturn previously held beliefs, it was commonly believed that the railroad was a key factor in economic growth. Joseph Schumpeter and Walt Rostow "had earlier, and with general agreement, asserted that modern economic growth was due to certain important discoveries having played a vital role in development. Fogel tested this hypothesis with extraordinary exactitude, and rejected it. . . . His use of counterfactual arguments and cost-benefit analysis made him an innovator of economic historical methodology." (Engerman et al xi) 
Fogel said that after he first estimated his social savings of the railroad, he got an unexpected result. His social savings was so low, he was convinced he had made an error. In trying to find where he made a mistake, he gradually convinced himself that he was right. (Lyons et al 334). He did not view his railroads work as an attempt to provoke controversy, but rather as a very careful, detailed study of the way in which a major innovation increased overall productivity. It was in attempting to answer the "how much?" question that he discovered, quite to his surprise, that the answer was "not much." (Lyons et al 335).

\section{Douglass North}

Douglass North had a rich and varied education, attending schools in the United States, Canada and Switzerland before enrolling at the University of California - Berkeley (BA 1942). While in high school he developed a passion - and obvious talent - for photography. He won several international awards and has continued to pursue photography as a hobby. His intention to enter law school was derailed by the war. He served in the Merchant Marines, which afforded him much time to read. His wide reading convinced him that economics, not law, was to be his calling. After the war he returned to Berkeley and completed his PhD in 1952, writing on the history of the U.S. life insurance industry under M.M. Knight.

North can be considered the grandfather of cliometrics because it was two of his students, Lance Davis and Jonathan Hughes, who organized the first meetings of the society at Purdue in 1960. North was in attendance at those inaugural meetings, and became an early and enthusiastic practitioner of this new form of economic history. He and his colleague, Morris D. Morris, trained an impressive group of economic historians who went on to become noted cliometricians.

When he switched his focus from American to European economic history in the late 1960s, he became convinced that the tools of neo-classical economic theory were not up to the task of explaining the kind of fundamental societal change that had characterized European economies from medieval times onward. His search for a suitable framework that would provide new tools of analysis led to his interest in the new institutional economics. The result was the publication of his signature book, Structure and Change in Economic History, in 1981. 
In Structure and Change he abandoned the notion that institutions were efficient and attempted to explain why "inefficient" rules would tend to exist and perpetuate. This was tied to a very simple and still neo-classical theory of the state that could explain why the state could produce rules that did not encourage economic growth.

The next step in his research occurred when he left the University of Washington after 33 years on the faculty and accepted the Luce Professorship of Law and Liberty in the Department of Economics at Washington University in St. Louis in 1983. It was there that North began working with political scientists and economists who were attempting to develop new models of political economy.

The development of a political-economic framework to explore long-run institutional change occupied him for the next decade and led to the publication of Institutions, Institutional Change and Economic Performance in 1990. In that book he began to puzzle seriously about the rationality postulate. He became convinced that the missing link was the explanation for why ideologies can shape the choices people make and direct the way economies evolve through long periods of time. Understanding ideologies requires an understanding of the way in which the mind acquires learning and makes choices. This was the focus of his research for the remainder of his life.

New Economic History, or Cliometrics, is a move from the more historical, descriptive, approach for the sake of describing a historical event, toward the use of economic theory to analyze an event. The first practitioners of the art of cliometrics "proposed that economic historians use the techniques and insights of modern economic theory to frame the questions asked of history, to influence the hypotheses advanced about the past, and to suggest the nature and type of data to be collected from the archives." (Engerman et al 71) Further, they advocated for the rigorous testing of any hypotheses advanced against the alternatives, particularly those found in the "old" economic history. This would require the collection of data and its analysis using econometric techniques - i.e. analysis of economic models.

So what was North looking for? In his 1965 AEA article he says p 86-87: "to the extent that economic history moves beyond the simple cataloguing of facts, it must meet of necessity the same set of standards that we attempt to impose by the use of scientific methods in economics." And further: "we frequently do not have either adequate theory or the statistical data 
to develop and test hypotheses in any definitive fashion ... [but] economic historians do not make use of the theory we do have."

Richard Sutch believes the most important link between North and cliometrics was his role as a missionary for the new economic history. In his role as co-editor of the JEH "he was able to ensure that the field's most prestigious journal was hospitable to articles and reviews that made self-conscious use of neoclassical economic theory and/or econometric methodology." 15 While editor, North published three papers $(1963,1965$, 1968) praising and evaluating the new economic history. He also published Growth and Welfare in the American Past in 1966. It is a collection of essays that use simple economic theory and tables of data to challenge views that were widely held at the time. It was important as the first, and for a long time only, textbook on new economic history suitable for undergraduates. The book was simply a set of examples of "accepted" historical facts that could be called into question with just the simplest application of economic theory. The ideas were largely undeveloped, laying out a gold mine for future research.

\section{Fogel and North and Clio}

Clio's moment in the spotlight, or fifteen minutes of fame, as Sam Williamson (1994) coined it, came at the 1964 AEA meetings. William Parker organized a session on "Economic History: It's Contribution to Economic Education, Research, and Policy," featuring papers by Douglass North (1965), Robert Fogel (1965), Barry Supple (1965), Richard Easterlin (1965), Robert Gallman (1965), and Rondo Cameron (1965), with comments by Evsey Domar and R. A. Gordon (1965). The session drew a crowd estimated at 200, generated lively discussion, and put cliometrics in a national spotlight that it had never previously experienced.

Fogel (1964b) highlighted the changes in economic history that justified its being "new." It was not a change in subject, they still remained interested in the description and explanation of economic growth. It was the approach to measurement and theory that was new. Economic history always had a quantitative dimension. But much of the past work had been limited to the simple organization of data contained in government and business records. While continuing this pursuit, the new economic history placed its primary emphasis on reconstructing measurements and organizing primary data in a manner allowing them to obtain measurements that were never before possible. It thus followed that the most critical issue in the work of the new economic 
historians was the logical and empirical validity of the theories on which their measurements were based.

The new economic historians made use of the whole gamut of economic theory and statistical models, and the measurements they obtain yielded considerably more precise information than previously available. The perfect example of this was Fogel's railroad study.

The publication of Railroads "represented a very major milestone - it was as if we now had proof that we had left the bumpy and unpaved dirt road of the first few years and could see ahead a straight and well-paved highway into the future," says Lance Davis in his review as part of Eh.net's Project 2000. The publication of Railroads generated an entire subdiscipline of parallel studies and, more importantly, provided a methodological foundation for the systematic study of economic history and long-term economic growth.

Railroads showed how well economic history could benefit from the careful application of theory and econometrics. The work immediately generated substantial controversy, and even today some quibbling over minor details occurs. However, time has failed to overturn Fogel's major conclusions: that per capita income growth would have been set back only a few months had the railroads never been invented, and there was no other industry that was likely to have been more important than the railroads. Since its publication, the great majority of economic history has been written by scholars employing those basic economic and econometric tools.

Perhaps the most influential book to come from the new economic history is North's Economic Growth of the United States, 1790-1860 (1961). What it lacked in thorough empirical research, it more than made up for in the way it clearly demonstrated how an economic model, theoretically sophisticated yet nonmathematical, could be employed to explain the organization and evolution of the various regions of the American economy over several decades.

In North's early work (1961 and 1966) he focused on the standard neoclassical explanations for economic growth (technology, human capital, technological change). But when he began to study European economic history he concluded that the neoclassical model was not able to explain the kind of fundamental societal change that had characterized European economies for the past 500 years. This led him down the path of what would become the new institutional economics, making him an early proponent of two different revolutionary schools of economic practice: cliometrics and new institutional economics. ${ }^{16}$ 


\section{Fogel and Railroads}

We focus our analysis on two works by Robert Fogel: "A Quantitative Approach to the Study of Railroads in American Economic Growth: A Report of Some Preliminary Findings," published in the Journal of Economic History in 1962, and Railroads and American Economic Growth: Essays in Econometric History (hereafter Railroads), published by Johns Hopkins University Press in 1964. The JEH article was essentially chapter two of the book. The railroad research is not remarkable so much for how frequently it was cited, but how wide ranging those citations were. The finding that the railroad was not the catalyst for economic growth previously thought was certainly important, and controversial, but the methodological innovation behind that finding was truly revolutionary.

The work that evolved from his pathbreaking study of the American railroads would inspire research in fields as far flung as anthropology, political science, sociology, geography, and law. ${ }^{17}$ Within the economics discipline, it spurred research in the areas of transportation economics, economic thought, theory, macroeconomics, real estate, and policy, just to name a few. Besides the expected economic history journals, development journals and general economic journals, ${ }^{18}$ his railroads work was cited in journals as disparate as the Journal of African Economies, Anthropozoologica, Ethics, Historical Methods, the Wisconsin Law Review, and the Journal of Corporate Finance. For a visual of the impact of his JEH piece, see Fig A.

Perhaps the most famous claim from Railroads was that "the most important implication of this study is that no single innovation was vital for economic growth during the nineteenth century." ${ }^{19}$ While it may not have been indispensable, it still may have been the single most important cause. The size (less than 5\% of GDP in 1890, or about three month's retardation of economic growth to that date) is the issue that Fogel set out to measure. His original goal was to measure just how big the contribution of the railroad was, and he concluded that it was not nearly as big as conventional belief held it to be. It wasn't that conclusion that makes this work a landmark, but the process by which he came to it. The application of econometrics and theory, careful attention to methodology, and the consideration of opportunity cost: what would have happened without the railroad,that sets this work apart as the gateway to cliometrics. 
Railroads was reviewed more than 20 times in the next two years. Even when it was not received positively, its impact on the field of economic history was acknowledged.

Lance Davis cited the roots of clio in the 1956 publication of Cary Brown's "Fiscal Policy in the Thirties: A Reappraisal," and a few months later, in Alfred Conrad and John Meyer's initial presentation of "The Economics of Slavery in the Ante-Bellum South." However, their findings, which have since been substantiated by further research, essentially served to preach to the already converted choir, and were generally accepted by neither historians nor economic historians, but the then small group of practitioners of the art-that-would-becomecliometrics. "Thus, cliometrics did not really begin to flower until the publication of Robert Fogel's study of the impact of railroads on American growth in the nineteenth century. Not only did it generate a spate of parallel studies (of Russia, Mexico, Brazil, England, and Scotland, to cite only five), but much more importantly, it provided a methodological foundation for the systematic study of economic history and long-term economic growth., 20

In his book, Fogel did two things. First, he debunked two widely held ideas: the indispensability of the railroad and the Rostow take-off thesis for America. Second, he demonstrated the virtues of applying quantitative methods and economic theory to history. ${ }^{21}$ In so doing, he made four important innovations that were to have a major impact on the future approach of research in economic history: "(1) the operational definition of social savings; (2) the use of an explicit counterfactual; (3) the use of a formal economic model to estimate what costs would have been had the decisions been made by economic man; and (4) his choice, when it was necessary to make assumptions about the actual world, of assumptions that were biased against his central findings. Even more than his estimates of interregional social savings, the work in this essay completely changed the way economic historians would do business in the future.,"22

"Although the work immediately generated substantial controversy, and even today one might quibble about a few days or a few months, in the long run, there has been little question about the book's major conclusion - that the level of per capita income achieved by January 1, 1890 would have been reached by March 31, 1890, if railroads had never been invented. Moreover, Fogel's work also indicated that there was no other industry that could have played the role that historiography attributed to the rails." ${ }^{23}$ 
In his 1995 JEH article seeking to find consensus among economic historians on critical issues in the discipline, one of the questions asked by Robert Whaples was "Without the building of railroads, the American economy would have grown very little during the nineteenth century." The responses were overwhelmingly on the side of Fogel. 89\% of economists surveyed, and 66\% of historians said they generally disagreed with the statement. A mere $9 \%$ of economists and $13 \%$ of historians agreed with the statement. $2 \%$ of economists and $21 \%$ of historians agreed only with provisions. ${ }^{24}$

The initial reviews of Railroads were largely positive. Meyer (p 87) called it "one of the best examples yet of the "new quantitative economic history." And Riegel (p 636) said that it "deserves serious consideration for both its methods and its conclusions." Further praise included that it demonstrated a "sophisticated quantitative approach [that] has added a significant new dimension to economic history." (Saul p 66) "Fogel's performance is an impressive one.... He is the new economic historian par excellence and his success as an innovator is best revealed by the rapidity with which academic entrepreneurs have adopted his techniques to their own problems." (Madden p 612)

Whitney ( $\mathrm{p}$ 276) predicted that Fogel's methodology pointed "the direction which economic historians will increasingly follow in the future . . . his vision opens historical research to a wide range of new analytical techniques." Indeed, Lance Davis (eh.net review) points out that Railroads served as a watershed in the practice of economic history. Since its publication "almost all economic history has been written by scholars who have either been trained in economics or who have found it necessary to acquire (either formally or informally) those basic economic and econometric skills."

Reviews at the time, whether critical or fawning, generally agreed that Fogel demonstrated remarkable "possibilities in using statistical inference and economic theory to answer significant historical questions." (Rothstein p131) "In large measure, the question is not so much whether one agrees with Fogel's conclusions. Rather, it is the competence and thoroughness of his analytical framework that commands attention." (Meyer p88) And Gould called it a rare book that reached "genuinely important conclusions on a genuinely important subject by applying novel methods to largely unused sources . . . a book which future economic historians may well remember as the book of its year, if not of its decade." (Gould 474) 
Williamson predicted that "it will leave a permanent mark on economic history and economic historians."(Williamson p110) Indeed, it is more widely cited today than it was in the years immediately following its publication. (Figure 1)

On the other hand, Fogel was also credited for his substantial traditional historical work. "The most impressive aspect of the book . . . is not its liberal application of methods often used by non-historical economists, but its traditional scholarship. Fogel's techniques are less striking than his use of imagination and a detailed knowledge of, and scrupulous regard for, the facts. . . In this sense, the break between the old and the new schools of economic history is not sharp at all." (Williamson p111) And Hilton (1966 p 237) found Fogel's RR book "probably the most impressive example of the union of theory, statistical technique and antiquarian digging."

Maybe the most prescient of the prognosticators was Goodstein, who noted Fogel's impact would forever change economic history, but warned that the "integration between it and economics will still remain somewhat less than complete until economists more frequently ask not what they can do for economic history but what it can do for them." (Goodstein 91)

Criticism was loud and immediate. Not everyone was a fan of the "new" economic history, particularly historians and "old school" economic historians who did not have the skills necessary to exploit the new tools the cliometricians brought to the academy.

Critics chided Fogel for his "counterfactual" approach, dismissing the idea that any such exercise could be carried out with any meaningful result (Erickson, Goodstein, Hacker, Kirkland, Saul, Scheiber), they criticized his technique (Hacker, Hilton, Madden, McClelland), and his data (McClelland), they chastised him for his (and by association, all cliometricians) condescending attitude toward the old economic historians (Kirkland), and they called into question the impact of his work on the discipline of economic history (Erickson, Hilton, Mitchell). But even some of the critics had to admire Fogel's efforts. As Harry Scheiber acknowledged, "The book is wrong, but brilliantly so.” (Scheiber p 278)

The most frequent criticism of Fogel's work was the counterfactual itself. Historians were wont to ask questions about hypothetical history, preferring to focus on events that actually occurred. As Kirkland complained, "Readers are bound to be distracted when they wake up in a world neither they nor any other American, except Fogel, ever made. . . The development he describes is not "what actually happened in the past." (Kirkland 1494) Rather, he opens "a new 
branch of literature, quite unlike what has hitherto passed as historical knowledge and somewhat more analogous to science fiction." (Erickson 107) Further, any counterfactual would have to consider all the related changes that would occur in the absence of the railroad. For example, he "does not consider the impact of railways upon the institutions of the capital market." (Erickson 109)

Econometrics and statistical analysis, familiar techniques to the economist, were foreign, unknown, and intimidating to many historians. As a result, this became a focus for criticism. "Economic analysis, using the tools of econometrics, is not enough and by itself capable of explaining causatively the process and structure of change and development. Political, social and legal historians, examining institutions, and social philosophers and sociologists, theorizing about them, have much to contribute. The hunt for invariant law in history - to explain the past, manipulate the present, and predict the course of the future - has all the dangers of a fall into a deep and possibly bottomless pit." (Hacker 1966 p 175) Others acknowledged the heroic efforts at data accumulation and the technical analysis thereof, but criticized the absence of any consideration of other important beneficiaries of the growth of the railroad, such as the development of a better capital markets, (Madden p 611) or the increased mobility of the populace, technological advances in the iron industry, and the international migration of labor to America. (McClelland)

Still others took umbrage at the tone of Fogel's arguments. "Here is another entry into the polemics between the new and the old economic historians. The good guys call themselves ... 'Cliometricians' and dismiss the bad guys as mere narrative historians. . . . This volume is a new manifesto which, if I get the message, threatens: Retool, rethink, conform, or be plowed under." (Kirkland 1493-94)

While most of the criticisms have proven to be either unfounded or weak, one has held up over time: that the cliometric movement espoused by Fogel's work would cleave the discipline. Erickson warned that "the exercise is without any doubt a brilliant tour de force, but it is more likely to widen than to narrow the area of communication between conventional historians and those who, like Professor Fogel, believe that in history as in economics it is only the methods of econometrics that offer real promise of enlightenment." (Erickson 107) Others were blunter: 
"There seems to be some danger in over-enthusiasm for a new "ism" - cliometricism!" (Mitchell p 603)

Writing in 1966, Louis Hacker lauded the accomplishments of Fogel and North, but cautioned that their methods were not better than, i.e. substitutes for, traditional (i.e. orthodox literary) economic history, but rather complementary to it, and they best not forget that if peace and cooperation between the economics and history disciplines was to be maintained.

A more general critique came from McAfee (1983). He lampooned Fogel and the social savings concept in a tongue-in-cheek article in which he suggests that a proper counterfactual would have had to go back much further than 1890 to discern the impact of the absence of the railway. He suggests a better point of departure would have been to hypothesize that Columbus had fallen off the end of the earth instead of discovering the American continents. Beginning in 1492, on a counterfactually imagined flat world, he then looks at the impact of such a failed voyage on the state of the world some 500 years into the future.

Criticism of the approach that Fogel took and the conclusions he reached about the role of the railroad was plentiful, but the more specific the complaints, the more difficult it actually became to unseat his argument. If not the railroad, then what? If Fogel mis-measured, or failed to consider some aspect of the railroad, then how would his critics demonstrate that he failed? What better data, what better formulated theory, what more clever mechanism could be unveiled to demonstrate that the railroad contributed $\mathrm{X} \%$ and not $\mathrm{Y} \%$ to growth? Fighting the Fogel findings with the vague generalizations that he argued against was ineffective. And the methods he pioneered have proven to be quite the opposite: they have endured for more than fifty years.

\section{The North editorial years}

Similar to Fogel's view on long-run relevance, North believed the true test of a scholar's contribution was not its popularity, but its staying power and ability to enliven the field. (Engerman et al, p 61) In this regard, we look at the impact that North had as an editor of the JEH on the impact and direction of cliometrics in the long run. Following on the work of Whaples, we construct a measure of "cliometrics" in the research published in the JEH by using graphs, tables, and equations, as proxies for the use of data and theory, counting their appearance 
in articles (including appendices) for every article published in the JEH from the first issue through 2013.

Douglass North and William Parker were appointed editors of the JEH in 1961, and would hold the position for six years. During this time period the rise of the "new" economic history was at the forefront of the discipline, and the JEH was its highest profile venue. As early practitioners of cliometrics, North and Parker viewed the approach favorably, and as editors were in a position to broaden its reach. Indeed, that is what they did, propelling the publication of clio influenced articles on a path that would lead the approach to dominance in the journal, as well as the field.

All was not smooth in this transition from the "old" to the "new" however. Midway through their six years at the helm, North and Parker were called before the Board of Trustees, ${ }^{25}$ dominated by the old guard, including Fritz Redlich, a vocal critic of the clio movement, and Hugh Aitken, a North adversary, and forced to defend themselves against charges of incompetence. Redlich was denouncing North and Parker and the articles they were publishing in the JEH. He was not alone, but was one of the most prominent critics. While Parker was diplomatic, North was furious, arguing that he and Parker were fair and balanced. He pointed out that in 1963 the acceptance rate of articles submitted by historians was actually higher than that for economists. ${ }^{26}$ Further, he noted that he and Parker did not agree on everything, and did not have an agenda. One example he cited was Fogel's railroad article, which North wanted to publish and Parker did not. While the momentum in the discipline was inevitably toward the new economic history methodology, it was not to the exclusion of the older, more traditional approach. Ultimately, North and Parker kept their positions, and served another three years, though not without the reluctant support of several trustees. ${ }^{27}$

In fact, by 1966, the landscape had changed considerably, and the Board actually considered appointing North and Parker for another three year term. Aitken and Redlich were no longer on the Board, replaced by "young turks" like Robert Gallman. North and Parker were not reappointed, but that did not end the drama over the choice for the new editor, which would influence the future direction of the JEH. 
There was an internal struggle within the Board over the future direction of the JEH. On the one hand, old school economic historians like Herman Krooss and Ralph Hidy, pushed for a return to a more historical approach, and favored the appointment of Hugh Aitken as solo editor of the JEH. Predictably, North, and other new practitioners, including Lance Davis and Parker, lobbied against the appointment of Aitken in particular, and in general, against anyone who opposed the cliometric trend. North argued that "no matter how you describe what has happened to American economic history in the last fifteen years, one thing is perfectly clear; that the trend is toward the use of economic analysis and the development of quantitative data, and this is not going to be reversed. I think any editorship should include at least one editor who is capable enough to evaluate such works. Aitken is not in that tradition and, in my opinion, does not have that capability... . I can think of a lot of people who might be picked as editors with the clear result that the Association would get torn to pieces. The new economic historians would simply be alienated." 28

Lance Davis echoed these sentiments, saying that “. . . if the decision is to go with a single economist as editor I think the choice of Hugh Aitken is not a good one. Although he might well be a person who is more acceptable to the traditionalists than some of the other obvious possibilities, I cannot visualize him doing the same kind of innovating editorial work that we have come to expect." 29 Parker's chief concern was that whoever was appointed editor be able to avoid splitting the profession between the old and new economic historians. ${ }^{30}$

The depth of the cavern forming between the two sides can be imagined from the perspective of the other side, the "old school" historians. Ralph Hidy lobbied for Hugh Aitken by arguing that "he has had experience as an editor, is a thorough scholar, and would strive to get balance between historians, economists, and the varieties of new and old economic history (I think)." ${ }^{31}$ Herman Krooss was less diplomatic, opining that he "could hardly think of a more damaging recommendation than that he [the new editor] is favored by the "new economic historians." 32

The traditionalists won the battle when Hugh Aitken was appointed to succeed North and Parker, but as history has shown, they lost the war. Aitken remained at the helm only two years before being replaced by Robert Gallman, a proponent and practitioner of the cliometric approach. Perhaps it was his brief tenure, or perhaps it was the inevitability of the cliometric 
movement, but the fears of North and the new economic historians were not borne out. The North-Parker years set the journal on a path of cliometric publishing from which it has not deviated. While the occasional "old school" narrative form of article has been published, it is a rarity.

North saw the 1960s as a period of massive transition in the economic history field, one that was not to everyone's liking, but that was inevitable. The landscape was changing, and he and Parker were mere pawns in a bigger game. The journal was getting new economic history submissions like Fogel's on the one hand, and then articles from Fritz Redlich on the other, and the journal published both. However, the movement was toward an increase in the cliometric approach, and inevitably, the purely narrative style of economic history began to fade. North felt like by the end of their tenure, the question as to whether the new economic history as a method was accepted had been answered in the affirmative. It was an acceptable and accepted part of economic history. The only real question was what proportion of the field it should be. ${ }^{33}$

A measure of the transition from new to old and its impact on the future direction of the discipline can be made by looking at the contents of the JEH. In order to gauge the impact of the North and Parker era (1961-66) relative to the other years, we use our clio proxy, counting the number of graphs, equations, tables, and citations. We consider three separate measures. The most inclusive is the sum of all graphs, tables, and equations. The most restrictive measure is just equations. The final measure counts only citations. In order to focus on the impact of the editors, we did not consider the Tasks issues of the journal. From 1941-1996 one issue of each volume was dedicated to papers delivered at the annual EHA meetings. Since these meetings were not under the same influence of the editors as the normally submitted papers, we eliminated them from the sample. From 1941-67 the Tasks issue was the December issue of the journal. In 1968 this was changed, and the fall meeting of 1968 was the focus of the March 1969 issue. The March issue continued to be the Tasks issue through 1983. From 1984-96 it migrated to the June issue, and beginning in 1997 the journal dropped the formal connection between the meetings and the journal. From the 1996 EHA meetings onward, papers presented at the conference were accorded no special treatment regarding submission or publication in the JEH. 
While the growth was not constant, the pattern is evident. (Figs 2 and 3) Equations per page and Equations, Graphs, and Tables per page both increased during the North-Parker years, and while there was a decrease immediately after their tenure, during the two year reign of Aitken, the pattern resumed and continued upward with the appointment of Gallman. The narrow measure of equations/page is more demonstrative of the impact that North and Parker had on the rise of clio style research in the JEH. Equations went from virtually nonexistent to commonplace, and never again fell to the depths observed before their editorship. The broader measure of graphs, tables, and equations had already exhibited a modest, albeit uneven, rise in the years immediately preceding the North-Parker term. The impact of citations/page is not as clear (Fig 4). Our examination of the three measures indicates that only the equations/page measure, the most conservative, led to a shift in the future level of clio publications.

\section{The Outliers methodology}

In assessing the impact of the North-Parker years on the trajectory of "cliometric" articles, we applied the outliers methodology. The basic assumption is to say that the regular shocks we observe (simply before our eyes) for the evolution of the time series are superposed by irregular shocks which appear rarely (infrequent large shocks, not possible to identify simply by looking on the figures). This includes the question whether the long-term development of our time series is caused (or not) by extraordinary shocks such as institutional changes or scientific policy measures, in the way of pushing cliometric research onward and upward. If this was the case, the development of cliometric research in the JEH could probably not be explained as a systematic endogenous process, but would have to be traced back to specific historical events.

We checked for two main outliers:

- $\quad$ Additive Outliers (AO) that affect only a single observation at some point in the time series and not its future values.

- $\quad$ Level Shifts (LS) that increase or decrease all the observations from a certain time point onward by some constant amount.

AOs are considered to be outliers, which are related to an exogenous and endogenous change in the series, respectively, and LSs are more in the nature of structural changes. We consider LSs to be the reflection of permanent shocks. 
If we examine the nature of the shocks on the series, we come to the following results. The table displays the results of outlier identification.

All detected outliers are given by series, with their timing (date) and type. Outliers are detected in all the series.

According to the calculations, we identify only one significant LS outlier in 1970. It seems that, ceteris paribus, in the JEH cliometrics develops significantly since that point! This could be the result (lag effect) of the scientific strategy engaged (the red color in the series) by North-Parker from 1961 to 1966.

When economic history takes an interest in the analysis of shocks, two main econometric methodologies can be engaged. Following the traditional approach, one can study shocks as impulse response functions. In that case the analysis is based on the estimation of a vector autoregressive (VAR) model and is part mainly of an analytical and forecasting approach as the envisaged shocks are simulated and hence fictitious. Following the most recent works in cliometrics, one can also analyse shocks as outliers. In that case, the analysis of shocks is part of an analytical and historical approach as the shocks are real. Our paper is part of this latter research path. In other words, we resort to the method of outliers. But how can these events, rare or extreme, be identified?

In statistical theory, when an observation departs strongly from the mean value or tendency, it is considered as exceptional. It is defined by a specific, non-representative value and their number usually does not exceed $1 \%$ of the time series. However the definition of these values, based solely on their size and rareness, is not operational. It is too vague and requires that size and frequency thresholds should be established beforehand, and those will help define whether a value can be called exceptional. After specifying the measurement scale and the reference period, we consider that an observation is of an exceptional character when its value (positive or negative) is very high and when its frequency is very low. Although this definition is subjective from a literal point of view, it allows us to sort-out these values into two categories: rare and extreme events. A rare event, also called an outlier, differs from an extreme event from the point of view of the frequency of occurrence. Whereas extreme values are grouped together, outliers are isolated. Hence, if events cannot be put into a homogeneous series, their nature 
changes and they become a-typical (outliers). In that respect, if they are isolated, they are outliers, and if not they are extreme.

Formally, outliers represent infrequent, large, temporary, and permanent shocks that affect a time series. There are several methods for detecting outliers. We use the procedure developed by Darné and Diebolt (2004, 2005).

Consider a univariate time series $y_{t}^{*}$ which can be described by the $\operatorname{ARIMA}(\mathrm{p}, \mathrm{d}, \mathrm{q})$ model:

$$
\alpha(B) \phi(B) y_{t}^{*}=\theta(B) a_{t}(1)
$$

where $B$ is the lag operator, $a_{t}$ is a white noise process, $\alpha(B), \phi(B), \theta(B)$ are the lagged polynomials with orders $d, p, q$, respectively. The outliers can be modelled by regression polynomials as follows:

$$
y_{t}=y_{t}^{*}+\sum_{I} \omega_{i} v_{i}(B) I_{t}(\tau)(2)
$$

where $y_{t}^{*}$ is an ARIMA process, $v_{i}(B)$ is the polynomial characterizing the outlier occurring at time $\mathrm{t}=\tau, \omega_{i}$ represents its impact on the series and $I_{t}(\tau)$ is an indicator function with the value 1 at time $t=\tau$ and 0 otherwise.

In theory, two main outliers (AOs and LSs) and two additional outliers (IOs and TCs) are classified as:

- $\quad$ Additive Outliers (AO) that affect only a single observation at some points in a time series and not its future values. In terms of regression polynomials, this type can be modelled by setting: $v_{1}(B)=1$.

- Innovational Outliers (IO), which produce a temporary effect for a stationary series, but produces a permanent level shift for a nonstationary series. The polynomial is then $\nu_{i}(B)=\theta(B) / \phi(B)$.

- $\quad$ Level Shifts (LS) that increase or decrease all the observations from a certain time point onward by some constant amount. In this case, the polynomial: $v_{i}(B)=1 /(1-B)$. 
- $\quad$ Temporary Changes (TC) that allow an abrupt increase or decrease in the level of a series, which then returns to its previous level exponentially rapidly. Their speeds of decay depend on the parameter $v_{i}(B)=1 /(1-\delta B)$, where $0<\delta<1$.

It is considered that AOs and IOs are outliers, which are related to an exogenous and endogenous change in the series, respectively, and that TCs and LSs are more in the nature of structural changes.

An ARIMA model is fitted to $y_{t}^{*}$ in (1) and the residuals are obtained:

$$
\begin{array}{r}
\hat{a}_{t}=\pi(B) Y_{t},(3) \\
\text { where } \pi(B)=\frac{\alpha(B) \phi(B)}{\theta(B)}=1-\pi_{1} B-\pi_{2} B^{2}-\ldots
\end{array}
$$

For the three types of outliers in (2), the equation in (3) becomes:

$$
\begin{aligned}
& \text { AO: } \hat{a}_{t}=a_{t}+\omega_{1} \pi(B) I_{t}(\tau) \\
& \text { IO: } \hat{a}_{t}=a_{t}+\omega_{2} I_{t}(\tau) \\
& \text { LS: } \hat{a}_{t}=a_{t}+\omega_{3}\left[\frac{\pi(B)}{(1-B)}\right] I_{t}(\tau) \\
& \text { TC: } \hat{a}_{t}=a_{t}+\omega_{2}\left[\frac{\pi(B)}{(1-\delta B)}\right] I_{t}(\tau)
\end{aligned}
$$

These expressions can then be viewed as a regression model for $\hat{a}_{t}$, i.e.,

$\hat{a}_{t}=\omega_{i} x_{i, t}+a_{t}$

With:

for all $i$ and $t<\tau: \quad x_{i, t}=0$

for all $i$ and $t=\tau: \quad x_{i, t}=1$ 


$$
\begin{aligned}
x_{1, t+k} & =-\pi_{k} \\
x_{2, t+k} & =0 \\
\text { for } t>\tau \text { and } k \geq 1: & \text { (AO); } \\
x_{3, t+k} & =1-\sum_{j=1}^{k} \pi_{j} \\
x_{4, t+k} & =\delta^{k}-\sum_{j=1}^{k-1} \delta^{k-j} \pi_{j}-\pi_{k}
\end{aligned}
$$

The test statistics for the types of outliers are given by:

$$
\begin{gathered}
\text { AO: } \hat{\tau}_{1}(\tau)=\left[\hat{\omega}_{1}(\tau) / \hat{\sigma}_{a}\right] /\left(\sum_{t=\tau}^{n} x_{1, y}^{2}\right)^{1 / 2} \\
\text { IO: } \hat{\tau}_{2}(\tau)=\hat{\omega}_{2}(\tau) / \hat{\sigma}_{a} \\
\text { LS: } \hat{\tau}_{3}(\tau)=\left[\hat{\omega}_{3}(\tau) / \hat{\sigma}_{a}\right] /\left(\sum_{t=\tau}^{n} x_{3, t}^{2}\right)^{1 / 2} \\
\text { TC: } \hat{\tau}_{4}(\tau)=\left[\hat{\omega}_{4}(\tau) / \hat{\sigma}_{a}\right] /\left(\sum_{t=\tau}^{n} x_{4, t}^{2}\right)^{1 / 2} \\
\sum_{i=\tau}^{n} \hat{a}_{t} x_{i, t} / \sum_{t=\tau}^{n} x_{i, y}^{2} \text { for } i=1,3,4 .
\end{gathered}
$$

and $\hat{\omega}_{2}(\tau)=\hat{a}_{t}$

where $\hat{\omega}_{i}(\tau)(i=1-4)$ denotes the estimation of the outlier impact at time $t=\tau$, and $\hat{\sigma}_{a}$ is an estimate of the variance of the residual process.

An outlier is identified at time $t=\tau$ when the test statistic $\hat{\tau}_{i}(\tau)$ exceeds a critical value. The critical value is determined by the number of observations in the series based on simulation experiments. The different test statistics at time $t=\tau$ are compared in order to identify the type of outlier. The one chosen has the greatest significance, such as $\hat{\tau}_{\max }=\max \left|\hat{\tau}_{i}(\tau)\right|$.

When an outlier is detected, we can adjust the observation $Y_{t}$ at time $t=\tau$ to obtain the corrected $Y_{t}^{*}$ via (2) using the $\hat{\omega}_{i}$, i.e. $Y_{t}^{*}=Y_{t}-\hat{\omega}_{i} v_{i} I_{t}(\tau)$. Finally, the procedure is repeated until no outlier is detected. A multiple regression on $Y_{t}^{*}$ is performed on the various outliers detected 
These results suggest that, ceteris paribus, the North-Parker editorial years positively contributed to the presence of economic theory and mathematical modelling in economic history. The presence of a level shift for the equations-only measurement is a significant illustration for that. It doesn't appear for the broader measure, which includes graphs and tables (measurement variabes) nor does it appear for the citations measure. Therefore, we claim that the North-Parker impact on the discipline was significant in permanently shifting it on a path that stressed cliometric analysis. They were critical in promoting, through the published research in the JEH, a shift in the belief that economic history should lay stress on measurements and that it should recognise the existence of close links between measurement and theory.

There is no doubt that the distinguishing feature of the level shift since the 1970s is the second characteristic and not the first. Indeed, unless it is accompanied by statistical and/or econometric processing and systematic quantitative analysis, measurement is just another form of narrative history. It is true that it replaces words with figures, but it does not bring in any new factors. In contrast, cliometrics is innovative when it is used to attempt to formulate all the explanations of past economic development in terms of valid hypothetico-deductive models. In other words, the essential characteristics of cliometrics is the use of these hypothetico-deductive models that call on the closest econometric techniques with the aim of establishing the interaction between variables in a given situation in mathematical form. This generally consists of constructing a model—of general or partial equilibrium-that represents the various components of the economic evolution in question and showing the way in which they interact. Williamson's (1974) general equilibrium model is a key reference here. Correlations and/or causalities can thus be established to measure the relative importance of each over a given period of time.

\section{Conclusion}

Economic historians have contributed to the development of economics in many ways, combining theory with quantitative methods, constructing and revising databases, and discovering and creating entirely new ones. This has made it possible to question and reassess earlier findings, thus increasing our knowledge, refining earlier conclusions, and correcting mistakes. In addition, this field has added greatly to our understanding of economic growth and development, affording the economic historian the valuable element of time as a variable, which 
the traditional theorist does not enjoy. The use of history to examine economic theory has deepened our knowledge and understanding within fundamental areas of research as to how, why, and when economic change occurs. It is perhaps in this area where the greatest contributions of economic historians have appeared.

By merging economic history with modern techniques, cliometricians have not ended economic history, but elevated it. The continuing evolution of technology has made a tremendous impact on the ability of cliometricians to handle ever larger data sets, share them with a wider audience, and access new data sets that previously took a lifetime to collate. While we may never be able to precisely measure the contributions that Robert Fogel and Douglass North have made to this progress, we know that those contributions were substantial.

In Railroads Fogel says "One cannot escape the ponderous problems of measurement in economic history by embracing qualitative analysis." ${ }^{34}$ In his review, George Rogers Taylor adds "Neither can one avoid making value judgments when choosing a particular model or making an assumption. The votaries of measurement need to be reminded that Fogel's admonition may well be reversed to read: One cannot escape the necessity for qualitative judgments by embracing quantitative analysis." 35 With this, Taylor set out the conundrum that has vexed cliometricians ever since: how to find the balance between economics and history. It is a narrow path indeed, and one we are still attempting to follow!

Figure A

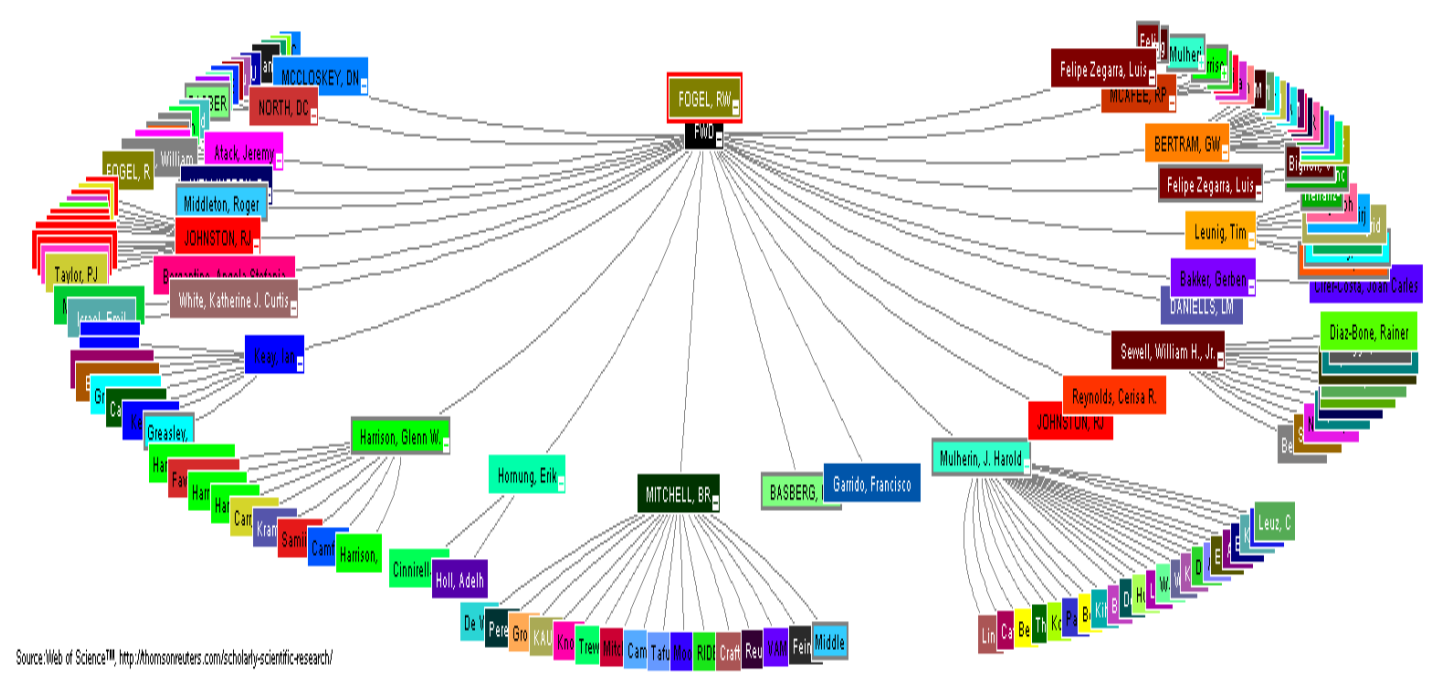


Figure 1

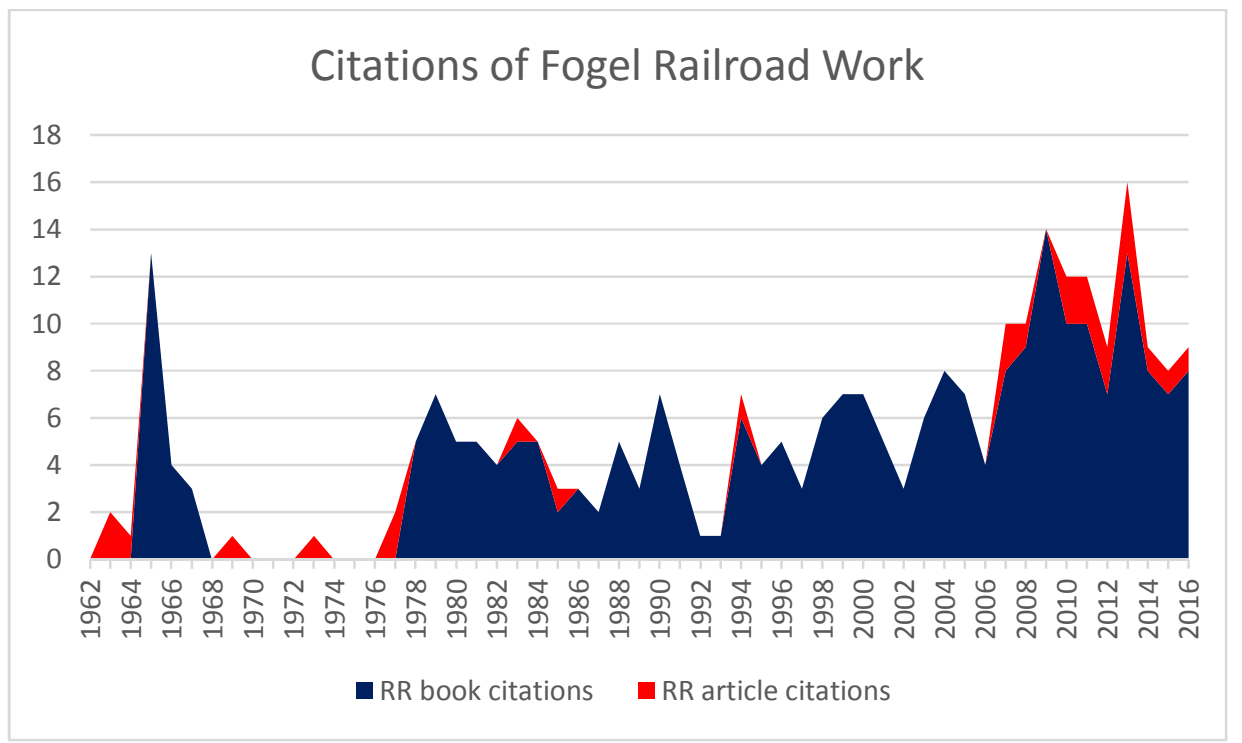

Figure 1a

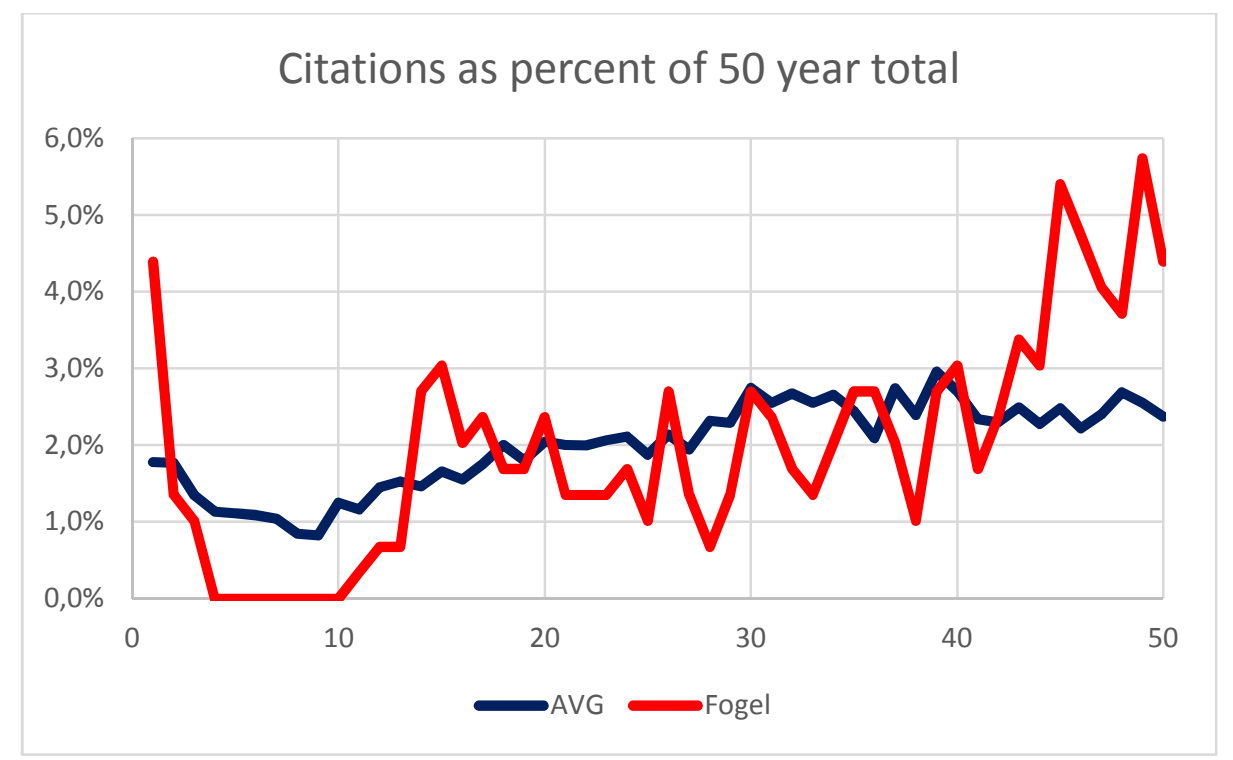


Figure 2

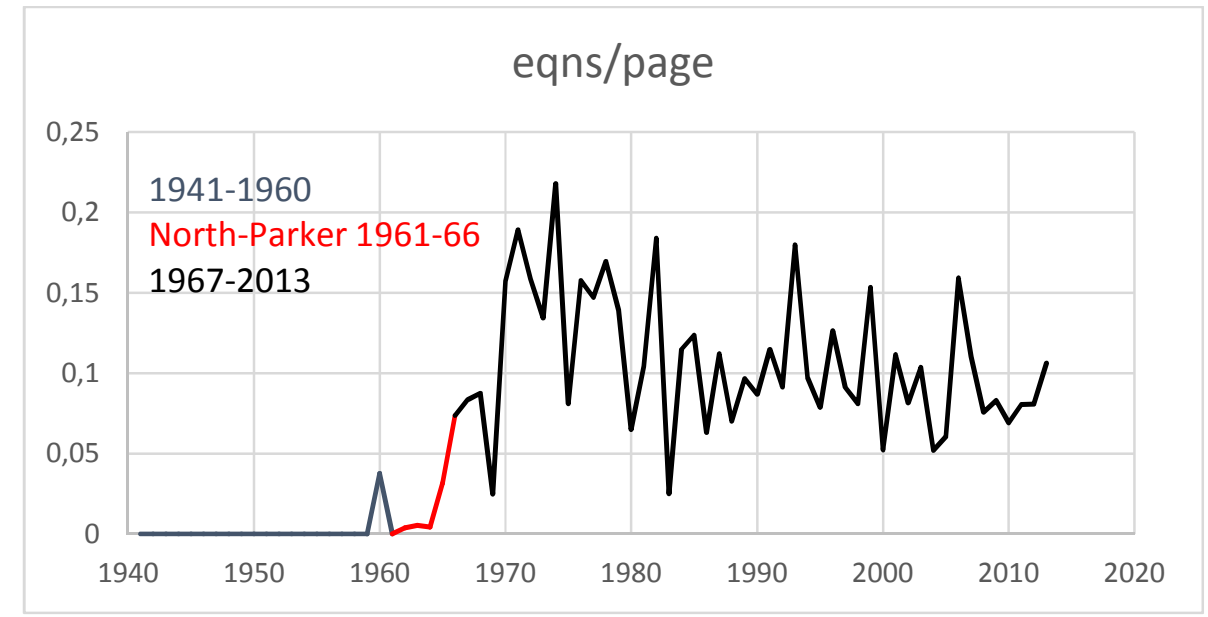

Figure 3

graphs, tables, eqns/page

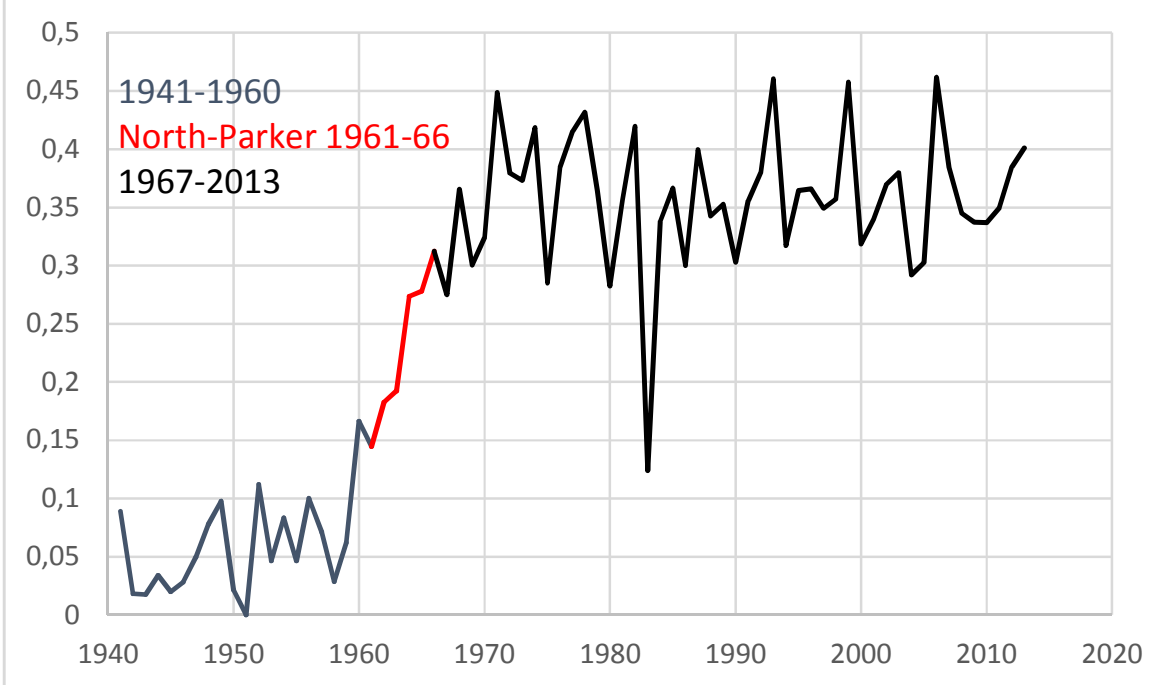


Figure 4

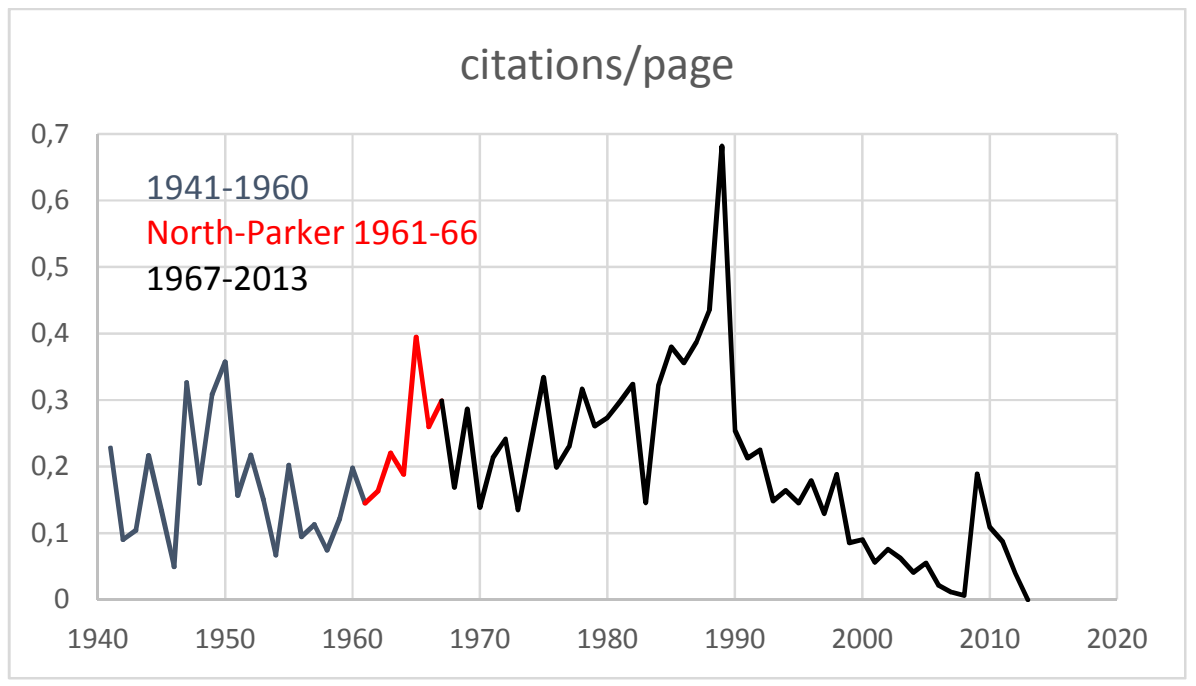

Table 1

\begin{tabular}{|c|c|c|c|}
\cline { 2 - 4 } \multicolumn{1}{c|}{} & AO and LS & Date & Type \\
\hline Series 1 & equations/page & 1970 & LS \\
\hline Series 2 & graphs, tables, equations/page & 1983 & AO \\
\hline Series 3 & citations/page & 1989 & AO \\
\hline
\end{tabular}




\section{Bibliography}

Anonymous, review of Railroads and American Economic Growth: Essays in Econometric History, by Robert William Fogel, Ethics 75, no. 3 (1965), pp 217

Brown, E. Cary, 1956. "Fiscal Policy in the Thirties: A Reappraisal," American Economic Review, 46 (December).

Carlos Ann, 2010: "Reflection on Reflections: Review Essay on Reflections on the Cliometric Revolution: Conversations with Economic Historians", Cliometrica, 4, pp 97-111

Cochran, Thomas C., "Recent Contributions to Economic History: The United States, The Twentieth Century," Journal of Economic History 19, no. 1 (March 1959), pp 64-75

Conrad, Alfred and Meyer, John, 1958. "The Economics of Slavery in the Ante-Bellum South" Journal of Political Economy, 66 (April). This paper was first presented at the meeting of the Economic History Association in 1956.

Darné, Olivier and Diebolt, Claude, 2004, "Unit Roots and Infrequent Large Shocks: New International Evidence on Output", Journal of Monetary Economics, 51, pp 1449-1465

Darné, Olivier and Diebolt, Claude, 2005, "Nonstationarity Tests in Macroeconomic Time Series", in: Diebolt C., Kyrtsou C., in collaboration with O. Darné (Eds.), New Trends in Macroeconomics, Springer, Berlin, pp 173-194

Davis, Lance E., Jonathan R. T. Hughes, and Stanley Reiter, "Aspects of Quantitative Research in Economic History," Journal of Economic History 20, no. 4, (December 1960), pp 53947

Davis, Lance, review of Railroads and American Economic Growth: Essays in Econometric History, by Robert William Fogel, project 2000, EH.net, (2000), http://eh.net/?s=railroads+and+american+economic+growth

Demeulemeester, Jean-Luc, and Diebolt, Claude, "How much could economics gain from history: the contribution of cliometrics," Cliometrica 1, no. 1, (April 2007), pp 7-17

Diebolt, Claude, "Cliometrica after 10 years: definition and principles of cliometric research", Cliometrica, 10, 1, 2016: 1-4

Diebolt, Claude, and Michael Haupert, eds., The Handbook of Cliometrics, Berlin: Springer Verlag, 2016

Diebolt, Claude, and Haupert, Michael, "Clio's Contributions to Economics and History," Revue d'Economie Politique 126, no. 5 (2016), pp 971-89

Easterbrook, W. T., "Recent Contributions to Economic History: Canada," Journal of Economic History 19, no. 1 (March 1959), pp 76-102

Economic History Association archives, Hagley Museum.

Engerman, Stanley L., Hughes, John R. T., McCloskey, Donald N., Sutch, Richard C., and Samuel H. Williamson, Two Pioneers of Cliometrics, Oxford: The Cliometric Society, 1994 
Erickson, Charlotte, review of Railroads and American Economic Growth: Essays in Econometric History, by Robert William Fogel, Economica 33, no. 129 (1966), pp 10609

Fishlow, Albert, American Railroads and the Transformation of the Ante-Bellum Economy, Cambridge: Harvard University Press, 1965

Fogel, Robert, The Union Pacific Railroad: A Case in Premature Enterprise. Baltimore: Johns Hopkins, 1960

Fogel, Robert, "The Social Saving Attributable to American Railroads in the Interregional Distribution of Agricultural Products in 1890: An Application of Mathematical-models to a Problem in History," Econometrica 29, no. 3 (1961), pp 475

Fogel, Robert, "Trends in the American Economy in the $19^{\text {th }}$ Century," Journal of Political Economy 69 no 5 (1961), pp 505-06

Fogel, Robert, "A Quantitative Approach to the Study of Railroads in American Economic Growth: A Report of Some Preliminary Findings," Journal of Economic History 22, no 2 (1962), pp 163-197

Fogel, Robert, "A Provisional view of the "New Economic History," American Economic Review (May 1964)

Fogel, Robert, Railroads and American Economic Growth: Essays in Econometric History. Baltimore: Johns Hopkins, 1964

Fogel, Robert, "The reunification of economic history with economic theory," American Economic Review (1965)

Fogel, Robert, "American interregional trade in the nineteenth century." In New Views on American Economic Development, ed. R. Andreano, 213-224. Cambridge, MA: Shenkman, 1965

Fogel, Robert, "Railroads and the axiom of indispensability". In New Views on American Economic Development, ed. R. Andreano, 225-241. Cambridge, MA: Shenkman, 1965

Fogel, Robert, "Railroads as an Analogy to Space Effort: Some Economic Aspects," Economic Journal 76, no. 301 (1966), pp 16-43

Fogel, Robert, "The new economic history: Its findings and methods." Economic History Review (1966) 19: 642-656

Fogel, Robert, "The new economic history: Its findings and methods," Economic History Review 19 (1966), pp 283-308

Fogel, Robert, "Notes on the Social Savings Controversy," Journal of Economic History 39, no. 1 (March 1979), pp 1-54

Goldin, Claudia, "Robert William Fogel remembrance," Cliometrica 8, no. 1, (January 2014), pp $1-3$

Goodrich, Carter, "Recent Contributions to American Economic History: the United States, 1789-1860," Journal of Economic History 19, no. 1 (March 1959), pp 25-43 
Goodstein, Marvin E., review of Railroads and American Economic Growth: Essays in Econometric History, by Robert William Fogel, Southern Economic Journal 32, no. 1 (1965), pp 90-91

Gould, J. D., review of Railroads and American Economic Growth: Essays in Econometric History, by Robert William Fogel, Economic Record 2, no. 99 (September 1966), pp 47575

Greenwood, Frank, review of Railroads and American Economic Growth: Essays in Econometric History, by Robert William Fogel, Southwestern Social Science Quarterly 46, no. 2 (1965), pp 176-77

Hacker, Louis, "The New Revolution in Economic History: A Review Article Based on Railroads and Economic Growth: Essays in Economic History, by Robert William Fogel," Explorations in Entrepreneurial History, second series, 3, no. 2 (Spring 1966), pp $159-175$

Harper, Lawrence, "Recent Contributions to American Economic History: American History to 1789," Journal of Economic History 19, no. 1 (March 1959), pp 1-24

Haupert, Michael, "The History of Cliometrics and its Impact on Economic History," in Claude Diebolt and Michael Haupert, eds., The Handbook of Cliometrics, Berlin: Springer Verlag, 2016, pp 3-32

Hilton, George W., review of Railroads and American Economic Growth: Essays in Econometric History, by Robert William Fogel, Explorations in Entrepreneurial History, second series, 3, no. 2 (Spring 1966), pp 234-238

Hughes, Jonathan R. T., "Fact and Theory in Economic History," Explorations in Entrepreneurial History [2d series] III, no. 2 (winter 1966), pp 75-100

Hutchins, John G. B., "Recent Contributions to Business History: The United States," Journal of Economic History 19, no. 1 (March 1959), pp 103-121

Kirkland, Edward, review of Railroads and American Economic Growth: Essays in Econometric History, by Robert William Fogel, American Historical Review 72, no. 4 (1967), pp 1493-95

LeDuc, Thomas, "Recent Contributions to American Economic History: American History18611900," Journal of Economic History 19, no. 1 (March 1959), pp 44-63

Lyons, John S., Louis P. Cain, and Samuel H. Williamson, eds., Reflections on the Cliometrics Revolution: Conversations with economic historians, New York: Routledge, 2008

Machlup, Fritz, The Political Economy of Monopoly: Business, Labor and Government Policies, Baltimore: Johns Hopkins University Press, 1952

Madden, John J., review of Railroads and American Economic Growth: Essays in Econometric History, by Robert William Fogel, Canadian Journal of Economics and Political Science 31, no. 4 (1965), pp 611-12

McAfee, R. Preston, "American Economic Growth and the Voyage of Columbus," American Economic Review 73, no 4 (September 1983), pp 735-40 
McClelland, Peter, "Railroads, American Economic Growth, and New Economic History Critique," Journal of Economic History 28, no. 1 (March 1968), pp 102-23

McCloskey, DN, "The Problem of Audience in Historical Economics: Rhetorical Thoughts on a Text by Robert Fogel," History and Theory 24, no. 1 (February 1985), pp 1-22

Meyer, John, review of Railroads and American Economic Growth: Essays in Econometric History, by Robert William Fogel, Journal of Political Economy 74, no. 1 (1966), pp 8788

Meyer, John, and Conrad, Alfred, "Economic Theory, Statisticl Inference, and Economic History," Journal of Economic History 17, not. 4 (December 1957), pp 524-44

Mitchell, B. R., review of Railroads and American Economic Growth: Essays in Econometric History, by Robert William Fogel, Journal of the Royal Statistical Society, series AGeneral 128, no. 4 (1965), pp 602-03

Nerlove, Marc, review of Railroads and American Economic Growth: Essays in Econometric History, by Robert William Fogel, Journal of Economic History 26, no. 1 (March 1966), pp 107-15

North, Douglass C., "Beyond the New Economic History," Journal of Economic History 34, no. 1 (March 1974), pp 1-7

Parker, William N., ed., Trends in the American Economy in the Nineteenth Century, Studies in Income and Wealth, vol 24, conference on Research in Income and Wealth, Princeton: Princeton University Press, 1960

Purdue Faculty Papers in Economic History, Herman C. Krannert Graduate School of Industrial Administration, Purdue University, Monograph Series, Homewood, IL: Richard D. Irwin, Inc., 1967

Redlich, Fritz, "NNew' and Tradititional Approaches to Economic History and Their Independence," Journal of Economic History 25, no. 4 (December 1965), pp 480-95

Riegel, Robert E., review of Railroads and American Economic Growth: Essays in Econometric History, by Robert William Fogel, Journal of American History 52, no. 3 (1965), pp 73536

Rothstein, Morton, review of Railroads and American Economic Growth: Essays in Econometric History, by Robert William Fogel, Business History Review 39, no. 1 (1965), pp 130-32

Rowney, Don Karl, and James Q. Graham, Jr. (eds), Quantitative History: Selected Readings in the Quantitative Analysis of Historical Data, Homewood, IL: The Dorsey Press, 1969

Saul, S. B., review of Railroads and American Economic Growth: Essays in Econometric History, by Robert William Fogel, Business History 8, no. 1 (1966), pp 65-67

Scheiber, Harry N., review of Railroads and American Economic Growth: Essays in Econometric History, by Robert William Fogel, Canadian Historical Review 47, no. 3 (1966), pp 277-79

Taylor, George Rogers, review of Railroads and American Economic Growth: Essays in Econometric History, by Robert William Fogel, American Economic Review 55, no. 4 (1965), pp 890-92 
Temin, Peter, "Economic History and Economic Development: New Economic History in Retrospect and Prospect," in Diebolt, Claude, and Michael Haupert, eds., Handbook of Cliometrics, Springer Reference: Heidelberg, 2016: 33-52

Walser, Peter, review of Railroads and American Economic Growth: Essays in Econometric History, by Robert William Fogel, Kyklos 18, no. 3 (1965), pp 552-53

Whaples, Robert, "A Quantitative History of the Journal of Economic History and the Cliometric Revolution," Journal of Economic History 51, no. 2 (June 1991), pp 289-301

Whaples, Robert, "The Supply and Demand of Economic History: Recent Trends in the Journal of Economic History,” Journal of Economic History 62, no. 2 (June 2002), pp 524-32

Whaples, Robert, "Where Is There Consensus Among American Economic Historians? The Results of a Survey on Forty Propositions," Journal of Economic History 55, no. 1 (March 1995), pp 139-54

Whitney, William G., review of Railroads and American Economic Growth: Essays in Econometric History, by Robert William Fogel, Journal of the American Statistical Association 61, no. 313, pp 275

Williamson, Jeffrey G., review of Railroads and American Economic Growth: Essays in Econometric History, by Robert William Fogel, Economic Development and Cultural Change 14, no. 1 (1965), pp 109-13

Williamson, Jeffrey G., Late Nineteenth-Century American Development: A General Equilibrium History, Cambridge University Press: London, 1974

\footnotetext{
${ }^{1}$ We thank Lee Alston, Stanley Engerman, Claudia Goldin, Sumner La Croix, Deirdre McCloskey, Robert Margo, Joel Mokyr, Larry Neal, and John Wallis for their feedback.

${ }^{2}$ A selection of the papers presented in these early meetings was published by Purdue University in 1967.

${ }^{3}$ The Cliometric Society was formally organized in 1983 by Sam Williamson and Deirdre (nee Donald) McCloskey.

${ }^{4}$ The first use of the term in print: "the logical structure necessary to make historical reconstructions from the surviving debris of past economic life essentially involves ideas of history, economics and statistics... has been labeled "Cliometrics." (Davis, Hughes, and Reiter 1960, p 540)

${ }^{5}$ Temin 2014

6 The Royal Swedish Academy of Sciences Press Release, 12 October 1993, Nobelprize.org, http://www.nobelprize.org/nobel_prizes/economic-sciences/laureates/1993/press.html

${ }^{7}$ Parts of this section are based on Haupert 2016

${ }^{8}$ See for example Engerman 1996, Floud 1991, Lyons, Cain and Williamson 2008, Williamson 1991 and 1994, and Williamson and Whaples 2003.

${ }^{9}$ Williamson and Whaples 2003 p 446

${ }^{10}$ Boldizzoni 2011. For earlier laments about the encroachment of theory and mathematics on the study of history, see Braudel 1949 and Polanyi 1944.

${ }^{11}$ Perhaps more than anyone, D.N. McCloskey has been responsible for holding all economists, not just economic historians, accountable for moving the frontiers of knowledge forward and not simply using the
} 
latest techniques to measure something because it can be measured. For example, see McCloskey 1978, 1985, 1987, 2006.

${ }^{12}$ For a different view of counterfactuals see Engerman (1980)

${ }^{13}$ See Fogel and Engerman 1974 and Fogel 2000, for example.

${ }^{14}$ Engerman et al 25

${ }^{15}$ Engerman et al p 73

${ }^{16}$ See Basu et al (1987), Galiani and Sened (2014), and Menard and Shirley (2014) for discussions of North's role in the new institutional economics movement.

${ }^{17}$ Throughout this work we use citations as a measure of influence.

${ }^{18}$ such as the AER, JPE, and JEL

${ }^{19}$ Fogel, Railroads, p234

${ }^{20}$ Lance Davis eh.net review

${ }^{21}$ see Mitchell, Nerlove, McClelland, Anonymous

${ }^{22}$ Lance Davis eh.net review

${ }^{23}$ Lance Davis eh.net review

${ }^{24}$ Whaples, JEH (1995), p143

251963 Board of Trustees members included Hugh Aitken, Martin Wolfe, JRT Hughes, Wayne Rasmussen, George Rogers Taylor, Fritz Redlich, Ralph Hidy, Herman Krooss, Thomas Cochran, Frederic Lane, EAJ Johnson, Shepard Clough, Rondo Cameron, Theodore Marburg, William Parker.

${ }^{26}$ EHA archives, folders 18-27, BoT meeting minutes, Sept 4, 1963, Club Room of the Carolina Inn at Chapel Hill NC

${ }^{27}$ Reflections on the Cliometrics Revolution: conversations with economic historians, eds. John S. Lyons, Louis P. Cain and Samuel H. Williamson, NY: Routledge, 2008).

${ }^{28}$ EHA archives, letter from North to William Parker dated Feb 11, 1966

${ }^{29}$ EHA archives, letter from Davis to Hal Williamson dated March 7, 1966

${ }^{30}$ EHA archives, Letter from Hal Williamson to Herman Krooss dated Feb 14, 1966

${ }^{31}$ EHA archives, letter from Hidy to Hal Williamson dated Mar 3, 1966

${ }^{32}$ EHA archives, Letter Krooss to Williamson dated Mar 7, 1966

${ }^{33}$ Lyons et al 201

${ }^{34}$ Fogel, Railroads, p 239

${ }^{35}$ Taylor, p 892 